American Journal of Applied Sciences 6 (1): 72-77, 2009

ISSN 1546-9239

(C) 2009 Science Publications

\title{
The Effect of Reaction Temperature on Retaining Oxirane Oxygen Contents in the Synthesis of Epoxidized Diethanolamides
}

\author{
${ }^{1,2}$ C.S. Lee, ${ }^{2}$ T.L. Ooi and ${ }^{1}$ C.H. Chuah \\ ${ }^{1}$ Department of Chemistry, Faculty of Science, \\ University of Malaya, Lembah Pantai, 50603 Kuala Lumpur, Malaysia \\ ${ }^{2}$ Advanced Oleochemical Technology Division, \\ Malaysian Palm Oil Board, P.O. Box 10620, 50720 Kuala Lumpur, Malaysia
}

\begin{abstract}
Epoxidized diethanolamides were synthesized by reacting diethanolamine (DEA) with mixture of Epoxidized Palm Olein $\left(\mathrm{EPO}_{\mathrm{o}}, 40 \% \mathrm{w} / \mathrm{w}\right)$ and Refined Bleached Deodorized Palm Kernel Olein $\left(\mathrm{RBDPKO}_{\mathrm{o}}, 60 \% \mathrm{w} / \mathrm{w}\right)$ at $1: 3$ molar at $80^{\circ} \mathrm{C}$ for $5 \mathrm{~h}$ and continued at $110^{\circ} \mathrm{C}$ for another $4 \mathrm{~h}$ of reaction time. Synthesized diethanolamides with high content of epoxides were reacted with isocyanate in the presence of $\mathrm{AlCl}_{3}$-THF complex catalyst to produce oxazolidone linkages in polyurethane network. The rigid polyurethane foam produced is of better quality as compared to the commercially available foam.
\end{abstract}

Key words: Amine value, epoxidized diethanolamides, FTIR, hydroxyl value, oxirane oxygen contents

\section{INTRODUCTION}

Alkanolamides is an important non-ionic surfactant using in the household products, personal care and cosmetic industries. Fatty alkanolamides, namely monoalkanolamide and dialkanolamide can be prepared by reacting fatty acids or fatty acid methyl esters with alkanolamine, such as monoalkanolamine or dialkanolamine at elevated temperature ${ }^{[1]}$. Lately, secondary fatty amides, such as alkanolamides have been reported to be synthesized by using triacylglycerides from tallow and tripalmitin to react with amine, such as ethanolamine, diethanolamine, ethylenediamine, diethylenediamine and others ${ }^{[2]}$. Besides, preparation of the ethanolamides by using laurel oil from black olive-sized fruits of Laurus nabilis L. has also been reported ${ }^{[3]}$. However, alkanolamides can also be used as one type of natural oil derived from polyols to produce rigid polyurethane foam. They can be prepared from the reaction of diethanolamine (DEA) with natural glycerides, such as soy bean, linseed, peanut and safflower oil ${ }^{[4]}$. The synthesis of diethanolamide polyol by using hydroxymethylated oil and carboxylated oil to increase the functionality of the polyol was used to prepare rigid polyurethane foams with the addition of Quadrol (N, N, N', N'- tetrakis [2hydroxypropyl] ethylenediamine $)^{[5,6]}$. Foams are improved in terms of high close cell contents, good dimensional stability and compression strength. Recently, diethanolamides has been successfully prepared from Refined Bleached Deodorized Palm Kernel Olein $\left(\mathrm{RBDPKO}_{\mathrm{o}}\right)$ with DEA in the presence of potassium acetate as catalyst ${ }^{[7]}$. Sieved empty fruit bunch fibres (EFB) from palm tree were also added as an organic filler to improve the mechanical properties of the rigid polyurethane foam. In other words, polyurethanes prepared from diethanolamides must be modified chemically or blended with other components in order to be sufficiently strong and stable.

Several studies reported that the introduction of heterocyclic groups namely isocyanurate, imide, phosphazene and oxazolidone to polyurethanes, could improve the thermal and mechanical properties of the foams ${ }^{[8-11]}$. The addition of oxazolidone groups to polyurethanes was usually performed by reacting isocyanates with epoxy compounds. Yaganeh and co-workers reported that the introduction of oxazolidones to polyurethane backbone from reacting glycidol with isocyanate-terminated polyurethane prepolymers improved the thermal and the stress-strain properties of the elastomers ${ }^{[12]}$. Although the epoxy groups in the middle of the fatty acid chain of triacylglycerides have lower reactivity towards isocyanate, Javni and co-workers found that the yield of oxazolidones is actually dependent on the type of catalyst used $^{[13]}$.

Corresponding Author: C.S. Lee, Department of Chemistry, Faculty of Science, University of Malaya, Lembah Pantai, 50603 Kuala Lumpur, Malaysia 
Therefore, we studied the synthesis of epoxidized diethanolamides from palm oil products. A series of epoxidized diethanolamides had been produced by using varying amount of Epoxidized Palm Olein $\left(\mathrm{EPO}_{\mathrm{o}}\right)$ and $\mathrm{RBDPKO}_{\mathrm{o}}$ to react with $\mathrm{DEA}^{[14]}$. The synthesized diethanolamides, consisting of reactive epoxy compounds, would provide extra cross-linking sites to allow the epoxides to react with diisocyanates to form oxazolidones during polyurethane foam production $^{[15]}$. The formation of oxazolidone linkage would happen at room temperature with the presence of an appropriate catalyst ${ }^{[16]}$. In the subsequent study, we proved that epoxides, retained in the diethanolamides, reacted with isocyanate during foam production in the presence of $\mathrm{AlCl}_{3}$-THF complex catalyst to form oxazolidone linkages in the polyurethane network ${ }^{[17]}$. The carbonyl stretch of oxazolidone was identified at $1750 \mathrm{~cm}^{-1}$ through FTIR analysis. Foams produced from higher OOC diethanolamides, reported to be more thermally stable than foams with lesser or without the presence of epoxides. Besides that, the mechanical properties, such as compression strength, thermal conductivity, close cell contents and dimensional stability of foams were improved by the epoxy compounds in the diethanolamides.

Nevertheless there were some breakings of epoxy ring in the diethanolamides when prepared at high reaction temperatures. In the previous study, there were $34.5 \%$ of epoxy ring breakings when the epoxidized palm olein $\left(\mathrm{EPO}_{\mathrm{o}}\right)$ reacted with diethanolamine at $110^{\circ} \mathrm{C}$ for $5 \mathrm{~h}^{[14]}$. Consequently, in the present work, we report on the preparation method at different temperatures to retain maximum percentage of oxirane oxygen contents in epoxidized diethanolamide products.

\section{MATERIALS AND METHODS}

Materials: $\mathrm{RBDPKO}_{\mathrm{o}} \quad$ (specifications: iodine value $=26 \mathrm{I}_{2} \quad \mathrm{mg} \quad 100 \quad \mathrm{~g}^{-1}$ sample, free fatty acid $=0.10 \quad \mathrm{mg} \quad \mathrm{KOH} \mathrm{g}^{-1}$ sample, saponification value $=250 \mathrm{mg} \mathrm{KOH} \mathrm{g}^{-1}$ sample) was obtained from Kempas Oil Sdn Bhd and $\mathrm{EPO}_{\mathrm{o}}$ (specifications: oxirane oxygen contents $=3.0 \%$, acidity $=1.1 \mathrm{mg} \mathrm{KOH} \mathrm{g}^{-1}$ sample, iodine value $=0.65 \mathrm{I}_{2} \mathrm{mg} 100 \mathrm{~g}^{-1}$ sample) was obtained from the pilot plant of Advanced Oleochemicals Technology Division (AOTD) of Malaysian Palm Oil Board (MPOB). Reagents: DEA (BASF), isopropyl alcohol (J.T. Baker), hydrobromic acid, $33 \mathrm{wt} \%$ solution in glacial acetic acid (ACROS ORGANICS), glacial acetic acid (J.T. Baker), were used as purchased. Chemicals: sodium acetate
(MERCK), eosin Y (ACROS ORGANICS), silver nitrate (DU LAB) and gelatin (MERCK) were used as purchased.

Synthesis of diethanolamides: The reaction was carried out in a one liter Pyrex glass reaction flask submerged in a silicone bath. The reaction flask was equipped with a mechanical stirrer, thermometer and condenser. $40 \%(\mathrm{w} / \mathrm{w})$ of $\mathrm{EPO}_{\mathrm{o}}$ was blended with $\mathrm{RBDPKO}_{\mathrm{o}}$ to react with DEA at molar ratio of 1: 3 [palm oil triacylglyceride (TAG): DEA]. The reaction was carried out at different temperatures until the sample was homogenous. Samples of the reaction mixture were withdrawn hourly to determine oxirane oxygen contents and total amine value.

Oxirane Oxygen Content (OOC): The OOC was not determined using the standard hydrobromic acid in acetic acid method ${ }^{[18]}$. This is because of the presence of DEA traces that will form amine-bromide complexes with $\mathrm{HBr}$ and interfere with the results of the determination test. The OOC was instead determined by using the back titration method described by A.J. Durbetaki, $1958^{[19]}$. The formation of amine-bromide complexes will be converted to amine acetate by sodium acetate. The procedure was as followed: $0.5 \mathrm{~g}$ sample was dissolved in $10 \mathrm{~mL}$ of glacial acetic acid in a $250 \mathrm{~mL}$ Erlenmeyer flask. Then, $25 \mathrm{~mL}$ of $0.1 \mathrm{M}$ hydrobromic acid in glacial acetic acid, $20 \mathrm{~mL}$ of $0.1 \mathrm{M}$ sodium acetate, 6 drops of eosin $\mathrm{Y}$ indicator and $0.1 \mathrm{~g}$ gelatin were added into the flask. Lastly, $30 \mathrm{~mL}$ water was added before the sample was titrated with $0.1 \mathrm{M}$ silver nitrate to an orange-crimson end point. A blank was carried out by adding $25 \mathrm{~mL}$ of $0.1 \mathrm{M}$ hydrobromic acid and $35 \mathrm{~mL}$ of $0.1 \mathrm{M}$ sodium acetate and titration was done as described above. The OOC was calculated using the following formula:

$$
\% \mathrm{OOC}=\frac{\left(\mathrm{V}_{1}-\mathrm{V}_{2}\right) \times \mathrm{M} \times 1.6}{\mathrm{~W}}
$$

where, $\mathrm{V}_{1}$ was the volume $(\mathrm{mL})$ of silver nitrate used in the titration of the blank, $\mathrm{V}_{2}$ was the volume $(\mathrm{mL})$ of silver nitrate used in the titration of the sample, $\mathrm{W}$ was the weight of the sample in gram and $M$ was the molarity of the hydrobromic acid solution.

Indicator method for total amine value determination: The total amine value is defined as the milligrams of potassium hydroxide equivalent to the basicity in one gram of sample. The analysis was based on the AOCS official method [20] but modified by 
dissolving $1.0 \mathrm{~g}$ of sample in $100 \mathrm{~mL}$ of isopropyl alcohol in order to obtain a more significant color change at the end point of the titration.

Fourier Transform InfraRed (FTIR) spectral analysis: Nicolet FTIR, Model: Magma-IR 550 spectrometry, series II was used to monitor the functional groups of the synthesized products. The sample was coated on potassium bromide pellets. Averages of 16 scans were recorded for every sample.

Hydroxyl Value Determination; The hydroxyl value is defined as the milligrams of potassium hydroxide equivalent to the hydroxyl content of one gram of sample. The hydroxyl value was determined by following the AOCS Official Method ${ }^{[21]}$.

Viscosity Measurement: The viscosity of the diethanolamides was measured by Brookfield DV-III Programmable Rheometer at 25 and $40^{\circ} \mathrm{C}$. To determine the viscosity, small amount of test sample (approximately $0.25 \mathrm{~g}$ ) was filled into the cone plate of the Rheometer. Test data will be gathered automatically by the computer program.

\section{RESULTS AND DISCUSSION}

Forty percent $(\mathrm{w} / \mathrm{w})$ of $\mathrm{EPO}_{\mathrm{o}}$ was blended with $\mathrm{RBDPKO}_{\mathrm{o}}$ as optimal starting material due to the diethanolamide products appeared as non-viscous liquid at room temperature with low viscosity as reported in another paper ${ }^{[14]}$. The staring material was then reacted with DEA at molar ratio of 1:3 (palm oil TAG: DEA) (Scheme 1). Glycerol was being produced as the byproduct of the reaction. However, it was not removed from the reaction mixture because it could help in cross-linking during the production of rigid polyurethane foam.

The optimum reaction temperature and reaction duration from the previous study were $110^{\circ} \mathrm{C}$ for $5 \mathrm{~h}^{[14]}$. Therefore, in this study, we tried to retain maximum oxirane oxygen contents in diethanolamide products by reacting the reaction mixture at lower temperatures, ranging from $110-80^{\circ} \mathrm{C}$. The reaction mixture was initially immiscible and separated into two layers, with the oil on the upper layer while the DEA stood at the bottom layer. When the two immiscible layers became homogenous, the epoxidized diethanolamides were formed and we discontinued the reaction. Sample was taken from the upper layer of the reaction mixture to study the changes of the oxirane oxygen contents. The epoxy functionality was retained more at lower reaction temperature (Fig. 1). The OOC of the diethanolamides,

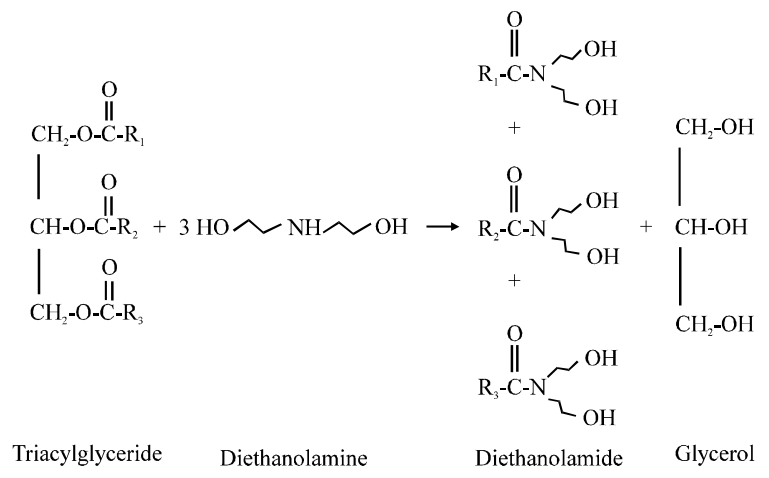

Scheme 1: Reaction scheme for the synthesis of diethanolamide. $R_{1}, R_{2}, R_{3}$ are alkyl chains with or without epoxide(s) functionality

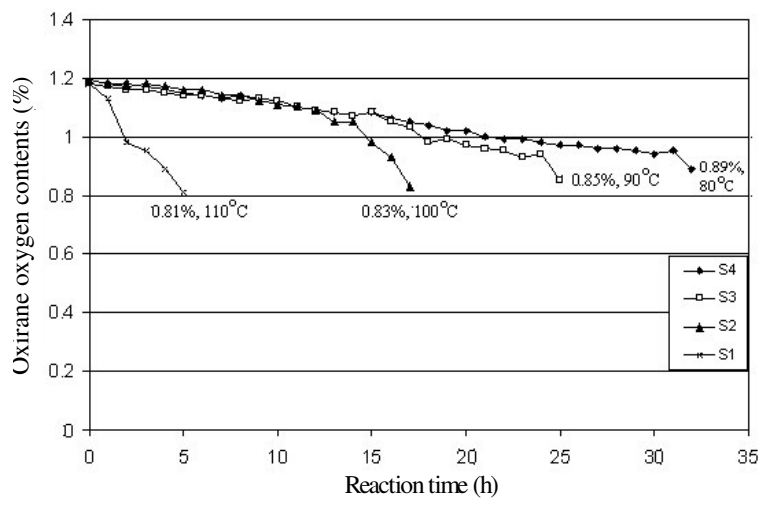

Fig. 1: Effects of reaction temperature on oxirane oxygen contents (S1-4). All samples were blended with $40 \%(\mathrm{w} / \mathrm{w})$ of $\mathrm{EPO}_{\mathrm{o}}$ and $60 \%$ $(\mathrm{w} / \mathrm{w})$ of $\mathrm{RBDPKO}_{\mathrm{o}}$ and reacted with DEA at 3:1 (TAG: DEA) molar ratio

Table 1: Percentage (\%) of oxirane oxygen contents retained (S1-4)

\begin{tabular}{|c|c|c|c|}
\hline $\begin{array}{l}\text { Sample } \\
\text { code }\end{array}$ & $\begin{array}{l}\text { Reaction } \\
\text { time }(\mathrm{h})\end{array}$ & $\begin{array}{l}\text { bxirane oxygen } \\
\text { contents }(\%)\end{array}$ & $\begin{array}{l}{ }^{\mathrm{c}} \mathrm{OOC} \\
\text { retained }(\%)\end{array}$ \\
\hline${ }^{\mathrm{a}} \mathrm{S} 1$ & 5 & 0.81 & 68.07 \\
\hline a $\mathrm{a} 2$ & 17 & 0.83 & 70.75 \\
\hline a $\mathrm{a} 3$ & 25 & 0.85 & 71.43 \\
\hline${ }^{\mathrm{a}} \mathrm{S} 4$ & 32 & 0.89 & 74.79 \\
\hline
\end{tabular}

synthesized at $80^{\circ} \mathrm{C}$ for $32 \mathrm{~h}$ managed to retain $74.79 \%$ of OOC from the starting material, whereas those reacted at 90,100 and $110^{\circ} \mathrm{C}$ only managed to retain $68-71 \%$ of OOC (Table 1). However, the reaction duration was long when reacted at $80^{\circ} \mathrm{C}$. Epoxy ring breakings were rapid at a high reaction temperature and long reaction duration. 
Am. J. Applied Sci., 6 (1): 72-77, 2009

Table 2: Reaction conditions to optimize oxirane oxygen contents

\begin{tabular}{ll}
\hline Sample code & Reaction conditions \\
\hline S5 & $80^{\circ} \mathrm{C}(5 \mathrm{~h})+110^{\circ} \mathrm{C}(4 \mathrm{~h})$ \\
S6 & $80^{\circ} \mathrm{C}(5 \mathrm{~h})+120^{\circ} \mathrm{C}(3 \mathrm{~h})$ \\
S7 & $80^{\circ} \mathrm{C}(5 \mathrm{~h})+130^{\circ} \mathrm{C}(2 \mathrm{~h})$ \\
S8 & $80^{\circ} \mathrm{C}(5 \mathrm{~h})+140^{\circ} \mathrm{C}(1 \mathrm{~h})$ \\
S9 & $80^{\circ} \mathrm{C}(5 \mathrm{~h})+150^{\circ} \mathrm{C}(40 \mathrm{~min})$ \\
S10 & $80^{\circ} \mathrm{C}(5 \mathrm{~h})+160^{\circ} \mathrm{C}(30 \mathrm{~min})$ \\
S11 & $80^{\circ} \mathrm{C}(5 \mathrm{~h})+170^{\circ} \mathrm{C}(1 \mathrm{~min})$ \\
\hline
\end{tabular}

Table 3: Percentage (\%) of oxirane oxygen contents retained (S5-11)

\begin{tabular}{lll}
\hline $\begin{array}{l}\text { Sample } \\
\text { code }\end{array}$ & $\begin{array}{l}\text { bxirane oxygen } \\
\text { contents }(\%)\end{array}$ & $\begin{array}{l}{ }^{\mathrm{c}} \text { OOC } \\
\text { retained }(\%)\end{array}$ \\
\hline${ }^{\mathrm{a}}$ S5 & 1.06 & 89.08 \\
${ }^{\mathrm{a} S 6}$ & 1.04 & 87.39 \\
${ }^{\mathrm{a} S}$ S & 1.02 & 85.71 \\
${ }^{\mathrm{a} S} 8$ & 0.98 & 82.35 \\
${ }^{\mathrm{a} S} 9$ & 0.96 & 80.67 \\
${ }^{\mathrm{a}}$ S10 & 0.95 & 79.83 \\
${ }^{\mathrm{a}}$ S11 & 094 & 78.99 \\
\hline
\end{tabular}

a: S5-11: Reaction conditions refer to Table 2;

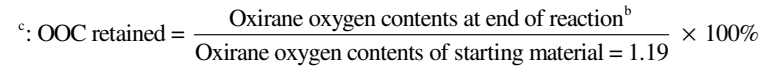

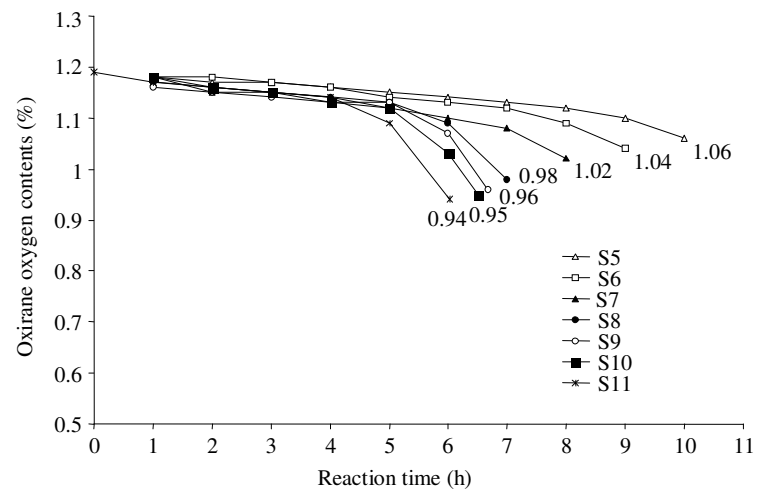

Fig. 2: Effects of reaction temperature on oxirane oxygen contents (S5-11). (i): Reaction conditions for samples S5-S11, refer to Table 2; (ii): All samples were blended with $40 \%$ (w/w) of $\mathrm{EPO}_{\mathrm{o}}$ and $60 \%(\mathrm{w} / \mathrm{w})$ of $\mathrm{RBDPKO}_{\mathrm{o}}$ and reacted with DEA at 3:1 (TAG: DEA) molar ratio

Therefore, we continued the study by reacting the reaction mixture at $80^{\circ} \mathrm{C}$ for $5 \mathrm{~h}$ and raised the reaction temperature to higher temperatures ranging from 110$170^{\circ} \mathrm{C}$ until the sample became homogenous (Table 2). Epoxy ring breakings were mild when reacted at $80^{\circ} \mathrm{C}$ for initial $5 \mathrm{~h}$ and raising the temperature for the following hour could help shorten the reaction time (Fig. 2). Diethanolamides from reaction S5 managed to retain $89.08 \%$ of OOC from the starting material (Table 3). The retained epoxy ring is expected to provide additional cross-linking sites by forming

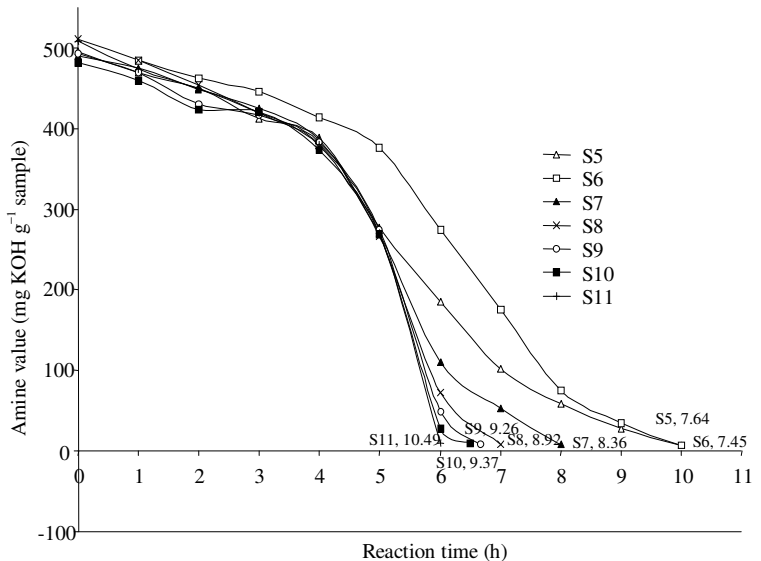

Fig. 3: Total amine value at different reaction temperature. (i) Reaction conditions for samples S5-S11, refer to Table 2; (ii): All samples were blended with $40 \%(\mathrm{w} / \mathrm{w})$ of $\mathrm{EPO}_{\mathrm{o}}$ and $60 \%$ (w/w) of $\mathrm{RBDPKO}_{\mathrm{o}}$ and reacted with DEA at 3:1 (TAG: DEA) molar ratio

oxazolidone during the preparation of rigid polyurethane foam. In our previous study, diethanolamides with higher percentage of OOC produced improved thermal conductivity, hardness and compressive strength of rigid polyurethane foam ${ }^{[17]}$.

Sample was taken from the bottom layer of the reaction mixture to study the changes of the amine value (AV) for sample S5-S11. The total amine value of the reaction mixture would decrease throughout the reaction and when the reaction temperature was raised to a higher temperature after $5 \mathrm{~h}$ of reaction at $80^{\circ} \mathrm{C}$, a sharp decrease in amine content was observed (Fig. 3). The total amine values in samples reacted at lower temperature and longer reaction time (S5, $\quad \mathrm{AV}=7.64 \mathrm{mg} \quad \mathrm{KOH} \quad \mathrm{g}^{-1}$ sample, S6, $\mathrm{AV}=7.45 \mathrm{mg} \mathrm{KOH} \mathrm{g}^{-1}$ sample) were lower compared to samples reacted at higher temperature and shorter reaction time $\left(\mathrm{S} 10, \mathrm{AV}=9.37 \mathrm{mg} \mathrm{KOH} \mathrm{g}^{-1}\right.$ sample, $\mathrm{S} 11, \mathrm{AV}=10.49 \mathrm{mg} \mathrm{KOH} \mathrm{g}^{-1}$ sample). This indicated that reactions $\mathrm{S} 5$ and $\mathrm{S} 6$ were more complete as compared to reactions $\mathrm{S} 10$ and $\mathrm{S} 11$.

FTIR study was subsequently used to monitor the reaction of diethanolamides. Figure 4 and 5 show that the sample underwent significant changes, particularly in the gradual appearance of the peak of $\mathrm{C}=\mathrm{O}$ stretching for tertiary amide at around $1625 \mathrm{~cm}^{-1}$. Another significant change was the gradual appearance of the broad peak, $\mathrm{OH}$ band at around $3396 \mathrm{~cm}^{-1}$. These changes indicated the gradual formation of the diethanolamides. Besides, the peak of C-O stretching 
Am. J. Applied Sci., 6 (1): 72-77, 2009

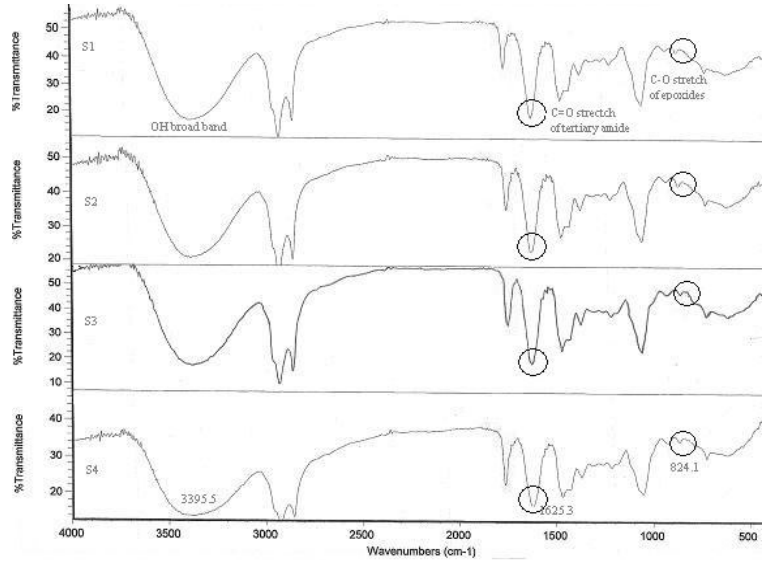

Fig. 4: FTIR analysis on samples S1-S4 to monitor the formation of $\mathrm{OH}$ band, $\mathrm{C}=\mathrm{O}$ stretching of $3^{\circ}$ amide and $\mathrm{C}-\mathrm{O}$ stretching of epoxides. (i): $\mathrm{S} 1$ : $110^{\circ} \mathrm{C}, \mathrm{S} 2$ : $100^{\circ} \mathrm{C}, \mathrm{S} 3$ : $90^{\circ} \mathrm{C}$ and $\mathrm{S} 4: 80^{\circ} \mathrm{C}$ (Reaction temperature); (ii): All samples were blended with $40 \%(\mathrm{w} / \mathrm{w})$ of $\mathrm{EPO}_{\mathrm{o}}$ and $60 \%$ $(w / w)$ of $\mathrm{RBDPKO}_{\mathrm{o}}$ and reacted with DEA at 3:1 (TAG: DEA) molar ratio

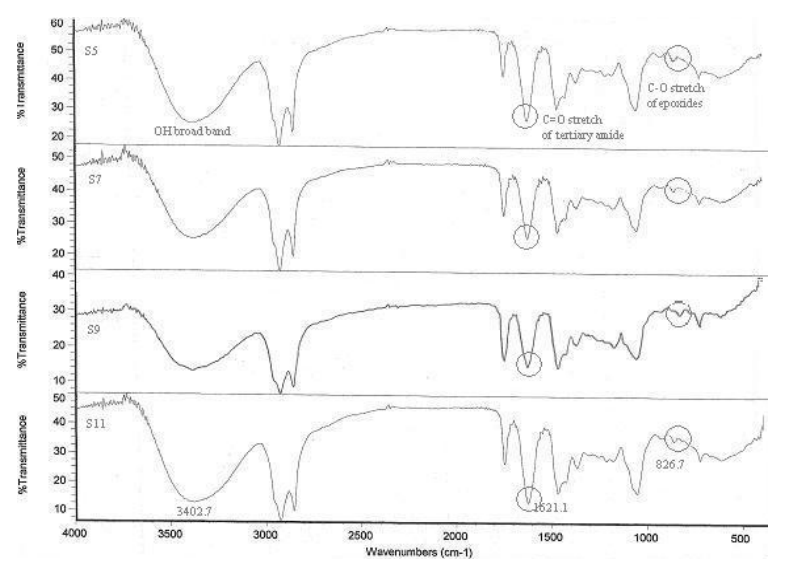

Fig. 5: FTIR analysis on samples S5-S11 to monitor the formation of $\mathrm{OH}$ Band, $\mathrm{C}=\mathrm{O}$ stretching of $3^{\circ}$ amide and $\mathrm{C}-\mathrm{O}$ stretching of epoxides. (i): Reaction conditions of samples S5-S11, refer to Table 2; (ii): All samples were blended with $40 \%(\mathrm{w} / \mathrm{w})$ of $\mathrm{EPO}_{\mathrm{o}}$ and $60 \%(\mathrm{w} / \mathrm{w})$ of $\mathrm{RBDPKO}_{\mathrm{o}}$ and reacted with DEA at 3:1 (TAG: DEA) molar ratio

for epoxy ring at around $824 \mathrm{~cm}^{-1}$ was observed, however the changes of percentage in transmittance were not significance due to the low percentage of epoxy compounds in the samples.

The hydroxyl value is no doubt important as it determines the suitability of the diethanolamides in the production of rigid or flexible polyurethane foam. The

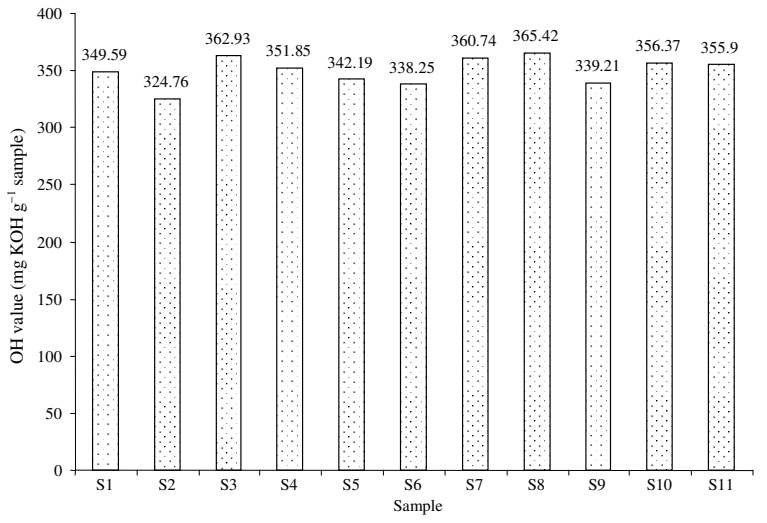

Fig. 6: Hydroxyl value of the diethanolamide products. (i): S1: $110^{\circ} \mathrm{C}, \mathrm{S} 2: 100^{\circ} \mathrm{C}, \mathrm{S} 3: 90^{\circ} \mathrm{C}$ and $\mathrm{S} 4$ : $80^{\circ} \mathrm{C}$ (Reaction temperature); (ii): Reaction conditions of samples S5-S11, refer to Table 2; (ii): All samples were blended with $40 \%$ $(\mathrm{w} / \mathrm{w})$ of $\mathrm{EPO}_{\mathrm{o}}$ and $60 \%(\mathrm{w} / \mathrm{w})$ of $\mathrm{RBDPKO}_{\mathrm{o}}$ and reacted with DEA at 3:1 (TAG: DEA) molar ratio

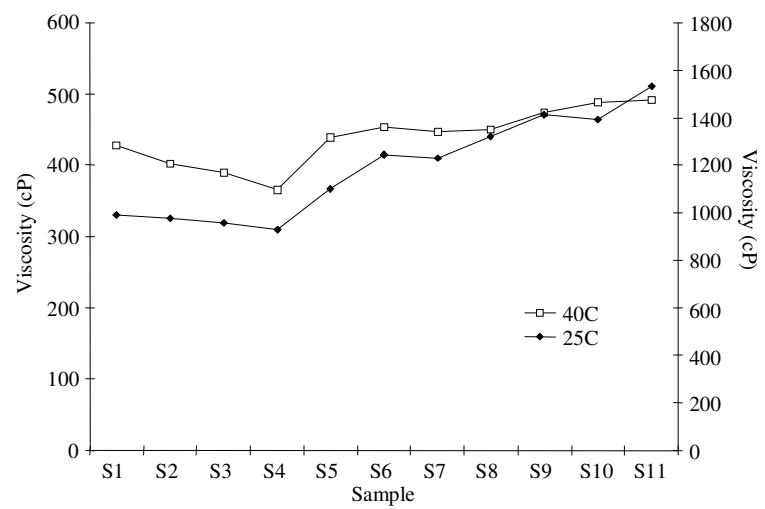

Fig. 7: Viscosity measurement on the synthesized diethanolamides. (i): $\mathrm{S} 1: 110^{\circ} \mathrm{C}, \mathrm{S} 2: 100^{\circ} \mathrm{C}, \mathrm{S} 3$ : $90^{\circ 000 \circ} \mathrm{C}$ and S4: $80^{\circ} \mathrm{C}$ (Reaction temperature); (ii): Reaction conditions of samples S5-S11, refer to Table 2; (ii): All samples were blended with $40 \%(\mathrm{w} / \mathrm{w})$ of $\mathrm{EPO}_{\mathrm{o}}$ and $60 \%(\mathrm{w} / \mathrm{w})$ of $\mathrm{RBDPKO}_{\mathrm{o}}$ and reacted with DEA at 3:1 (TAG: DEA) molar ratio

synthesized diethanolamides exhibit high hydroxyl values in the range of $320-370 \mathrm{mg} \mathrm{KOH} \mathrm{g}^{-1}$ sample (Fig. 6). The hydroxyl values is found to be quite similar to the hydroxyl values $\left(300-370 \mathrm{mg} \mathrm{KOH} \mathrm{g}^{-1}\right.$ sample) of the carboxylated diethanolamides and palm oil-based diethanolamides used in the production of rigid polyurethane foams ${ }^{[6,7]}$.

At last, viscosity of the final products of each reaction was measured at $25^{\circ} \mathrm{C}$ and $40^{\circ} \mathrm{C}$ (Fig. 7). By 
reacting the reaction mixture at a lower temperature (S2, S3, S4), a less viscous diethanolamides could be produced. Nonetheless, samples that reacted at a higher reaction temperature (S5-S11) performed as higher viscosity products.

\section{ACKNOWLEDGEMENTS}

This study was supported by the Malaysian Palm Oil Board Graduate Research Grant.

\section{REFERENCES}

1. Shapiro, S.H., 1968. Commercial Nitrogen Derivatives of Fatty Acids. In: Fatty Acids and Their Industrial Applications, Pattison, E.S. (Ed.). Marcell Dekker, Inc., New York, pp: 77-154.

2. Feairheller, S.H., R.G. Bistline, A. Bilyk Jr., R.L. Dudley, M.F. Kozempel and M.J. Haas, 1994. A novel technique for the preparation of secondary fatty amides. III. Alkanolamides, diamides and arylamides. J. Am. Oil Chem. Soc., 71: 863-866.

3. Kolancilar, H., 2004. Preparation of laurel oil alkanolamide from laurel oil. Ibid., 81: 597-598.

4. Wolft, P., Farum and H. Larsen, 1972. Polyurethane prepared from glyceride reaction products. U.S.P. 3, 637, 539.

5. Khoe, T.H., F. Otey. E.N. Frankel and J.C. Cowan, 1973. Poyurethane foams from hydroxymethylated fatty diethanolamides. J. Am. Oil Chem. Soc., 50: 331-333.

6. Khoe, T.H. and E.N. Frankel, 1976. Rigid polyurethane foams from diethanolamides of carboxylated oils and fatty acids. Ibid., 53: 17-19.

7. Badri, K.H., Z. Othman and S.H. Ahmad, 2004. Rigid polyurethane foams from oil palm resources. J. Mater. Sci., 39: 5541-5542.

8. Dick, C., E. Dominguez-Rosado, B. Eling, J.J. Liggat, C.I. Lindsay and S.C. Martin, 2001. The flammability of urethane-modified polyisocyanurates and its relationship to thermal degradation chemistry. Polym., 42: 913-923.

9. Yeganeh, H., M. Barikani and F.N. Khodabadi, 2000. Synthesis and properties of novel thermoplastic poly(urethane-imide)s. Eur. Polym. J., 36, 2207-2211.

10. Radhakrishnan Nair, P., C.P. Reghunadhan Nair and D.J. Francis, 1996. Phosphazene- modified polyurethanes: Synthesis, mechanical and thermal characteristics. Ibid., 32, 1415-1420.
11. Lee, Y., W. Ku, J. Tsou, K. Wei and P. Sung, 1991. Epoxy modified polyurethane rigid foams. J. Polym. Sci.: Part A: Polym. Chem., 29: 1083-1088.

12. Yeganeh, H., S. Jamshidi and P.H. Talemi, 2006 Synthesis, characterization and properties of novel thermally stable poly(urethane-oxazolidone) elastomers. Eur. Polym. J., 42: 1743-1754.

13. Javni, I., A. Guo and Z.S. Petrovic, 2003. The study of oxazolidone formation from 9, 10epoxyoctadecane and phenylisocyanate. J. Am. Oil Chem. Soc., 80: 595-600.

14. Lee, C.S., T.L. Ooi, C.H. Chuah and S. Ahmad, 2007. Synthesis of palm oil-based diethanolamides. J. Am. Oil Chem. Soc., 84: 945- 952.

15. Korshak, V.V., V.A. Pankratov, L.I. Komarova, Ts.M. Frenkel, A.M. Fainleib and S.V. Vinogradova, 1983. Reaction of cyanurates with the epoxide ring. Russ. Chem. Bull., 32: 2135-2138.

16. Ashida, K., 1980. Complex Catalysts for Oxazolidone Formation. In: International Progress in Urethanes, Ashida, K. and Frisch, K.C. (Ed.). TECHNOMIC Publication, West Port, CT, pp: 144-156.

17. Lee, C.S., T.L. Ooi, C.H. Chuah and S. Ahmad, 2007. Rigid polyurethane foam production from palm oil-based diethanolamides. J. Am. Oil Chem. Soc., 84: 1161- 1167.

18. AOCS Official Method Cd 9-57, 1993. Oxirane Oxygen. In: Official Methods and Recommended Practices of the American Oil Chemists' Society. 4th Edn. AOCS Press, Champaign, USA.

19. Durbetaki, A.J., 1958. Determination of oxirane oxygen in salts of epoxy acids and in the presence of amines. Anal. Chem., 30: 2024-2025.

20. AOCS Official Method Tf 1b-64, 1993. Total Amine Value of Fatty Amines, Indicator Method. In: Official Methods and Recommended Practices of the American Oil Chemists' Society. 4th Edn. AOCS Press, Champaign, USA.

21. AOCS Official Method Cd 13-60, 1993. Hydroxyl Value. In: Official Methods and Recommended Practices of the American Oil Chemists' Society, 4th edn. AOCS Press, Champaign, USA. 